\title{
Empathy and Low Participation of Women in Engineering: Is There a Hidden Link
}

\author{
Yonghong Jade $\mathrm{Xu}^{1}$, Eddie Jacobs ${ }^{2}$, Carmen Astorne-Figari ${ }^{3}$, Amy L. de Jongh Curry ${ }^{2}$, Shelby G. Roberts ${ }^{1}$, Russell \\ J. Deaton ${ }^{2}$ \\ ${ }^{1}$ College of Education, University of Memphis, Memphis, Tennessee \\ ${ }^{2}$ College of Engineering, University of Memphis, Memphis, Tennessee \\ ${ }^{3}$ Department of Economics, University of Memphis, Memphis, Tennessee \\ Correspondence: Yonghong Jade Xu, Counseling, Educational Psychology and Research, Ball Hall 100, University of \\ Memphis, Memphis, TN 38152, USA.
}

Received: May 11, 2021

doi:10.11114/jets.v9i6.5237
Accepted: June 2, $2021 \quad$ Online Published: June 19, 2021

URL: https://doi.org/10.11114/jets.v9i6.5237

\begin{abstract}
Women are severely underrepresented in science, technology, engineering, and mathematics (STEM) education and the related work force. One of the reasons for the low presence of women in engineering is a lack of connection between engineering-related values and women's personal values and beliefs, in particular the difference in empathy value. This study examined how empathy may have contributed to the low enrollment of women in engineering majors. An online survey was used to collect data from undergraduate students in an urban university in the United States. Statistical procedures were carefully selected to analyze the survey data and answer the four research questions. The results indicate that 1) students with a stronger empathizing trait reported lower likelihood of majoring in engineering; and 2) the perceived empathy level of a given academic discipline was a significant factor in students' major choice. The lower likelihood of majoring in engineering was associated with its low empathy level perceived by the students. The major findings of the study call for reformulation of the engineering education so that human-centered values can be emphasized as critical components to the existing curricula.
\end{abstract}

Keywords: empathy, gender disparity, engineering education; professional values

\section{Introduction}

\subsection{Introduce the Problem}

A growing body of literature has examined the underrepresentation of women in science, technology, engineering, and mathematics (STEM) education and the related work force. A variety of factors, ranging from individual and cultural, to structural and organizational, have been found to contribute to the lack of gender balance in STEM fields (Griffith, 2010; Zhang, 2008; Xu, 2015). However, great variations exist among STEM majors. For example, health/life science majors have sufficient female presence, with women receiving roughly $55 \%$ of bachelor's degrees in health and bioscience related majors $(\mathrm{Xu}, 2016)$, whereas recent statistics show that roughly $20 \%$ of engineering degrees are awarded to women, with only $14 \%$ of the engineering workforce being female (Dizikes, 2016). Given the lack of changes in the status quo of women in engineering, more scholarly efforts are needed to identify and change the factors that may alienate women from participating in engineering fields. Motivated by studies (e.g., Fox, Sonnert, \& Nikiforova, 2011; Matusovich, Streveler, \& Miller, 2010; Strobel, Hess, Pan, Wachter, \& Morris, 2013) that suggest women often experience a lack of connection between engineering-related values and their sense of self, the objective of this study is to empirically examine how male and female college students vary in their empathy levels and assess the role empathetic factors play in individuals' choice of engineering majors.

\subsection{Explore Importance of the Problem}

A core principle of the National Society of Professional Engineers (NSPE) holds that the knowledge and skills possessed by an engineer are to be used to the advancement and benefit of human welfare (NSPE, 2018). Similarly, the concept of social responsibility in engineering is also espoused by most of the professional organizations in engineering (ABET, 2018; ASCE, 2017; ASEE, 2012; IEEE, 2018; Kirkpatrick et al., 2011). For example, the Institute for Electrical 
and Electronic Engineers (IEEE) has adopted the mission of fostering "technological innovation and excellence for the benefit of humanity" (IEEE, 2018). However, in reality, the teaching and learning activities in most engineering programs concentrate on the development of knowledge and skills, with little emphasis on how those skills will be applied to benefit humanity (Cech, 2014). Past examination of the motivations and attitudes of engineering students finds that the benefit to mankind is often perceived as largely absent from consideration. With the ethical obligation of engineering professions to "hold paramount the health, safety and welfare of the public" (NSPE, 2018), the need is paramount for engineering programs to foster a focus on and valuing of others and of the public (Cech, 2014).

\subsection{Review of Literature}

Since 1990 women have consistently comprised only $14 \%$ of the engineering workforce (NSF, 2014). In dealing with the problem of the underrepresentation of women in engineering, many have sought to eliminate the gender-biased structural/institutional barriers in hopes of increasing women's involvement. However, an increasing body of evidence suggests that, besides structural and organizational barriers, the core values upheld in engineer fields and the current owned identity of engineers are perceived as having little concern for the welfare of others. Such professional values and identities appear to be disconnected from the social elements and values emphasized by women in general, and the disconnection may be a barrier for women to enter engineering disciplines (Faulkner, 2000; Matusovich et. al., 2010; Penprase, Oakley, Ternes, \& Driscoll, 2015; Rasoal, Danielsson, \& Jungert, 2012). Therefore, in this study we chose to approach the disparity between genders in engineering from the perspective of empathy. Specifically, empathy is defined as an individual's ability to identify on an emotional level with another person, group, or society as a whole, coupled with a desire to help them (Myyry \& Helkama, 2001; Penprase et al., 2015; Rasoal et al., 2012). The focus on empathy as a factor in the participation of women in engineering is based on the following considerations: 1) the concept of empathy is often studied as a factor in professional identities; 2) there are significant gender differences in identity and personality traits; and 3) empathy is typically low among engineering students and faculty.

\subsubsection{Empathy Is part of the Creation of Profession Identities}

Professional identity can be described as the values, knowledge, skills, attitudes, and beliefs that are shared with others in the same professional group (Adams, Hean, Sturgis, \& Clark, 2006; McGowen \& Hart, 1990). Professional identity is a matter of subjective self-conceptualization associated with the work and professional role being undertaken by an individual. In other words, professional identity is an integral part of an individual's personal identity (Carlsen, Hermansen, \& VraÊle, 1984), and the existence of a personal identity is a prerequisite for the development of a professional identity (Öhlén \& Segesten, 2002). As such, individuals' occupational choices are strongly related to their personal values and beliefs (Adams et al., 2006; Myyry \& Helkama, 2001).

Among other personal characteristics, empathy has been frequently studied as a factor in professional identity (Jacobs, de Jongh Curry, Deaton, Astorne-Figari, Strohmer, 2016; Myyry \& Helkama, 2001; Öhlén \& Segesten, 2002). Studies found that women have a lower connection between their own identity and an engineering identity (Heyman, Martyna, \& Bhatia, 2002), and one strong mismatch between women and engineering is with level of empathy (Jacobs et al., 2016). Empathy is an important part of women' identity, whereas engineering disciplines are perceived as lacking empathy as a core element and having little concern for the welfare of others (Cech, 2014; Jacobs et al., 2016). As additional evidence that the empathy mismatch may be a barrier to entry for women, Matusovich, Streveler, and Miller (2010) found that women have difficulty connecting with the owned identity of engineers; and when students' values and identities aligned with engineering values and identities they were more likely to persist in engineering degrees.

\subsubsection{Gender Differences in Empathy}

In general women are measured much higher than men on emphasizing profiles and empathy-biased minds (e.g. Baron-Cohen, Richler, Bisarya, Gurunathan, \& Wheelwright, 2003; Andrew, Cooke, \& Muncer, 2008; Rasoal et al., 2012; Willer, Wimer, \& Owens, 2015). In other words, women have a stronger tendency to identify another person's thoughts and emotions and to respond to this with appropriate emotions of their own. Empirical findings support the notion that women have higher empathic response than men (Groen, Fuermaier, Den Heijer, Tucha, \& Althaus, 2015). For example, Rasoal et. al. (20112) performed a study on students in a number of disciplines including nursing, medicine, social work, psychology, applied physics, and computer engineering and found that applied physics and computer engineering students were less empathetic and that "engineering students have significantly lower empathy than students from other programmes" (p. 433). However, once corrections were made for the effect of sex only a few significant differences remained, indicating that substantial gender difference exists on the development of empathy. In addition, Penprase et al. (2015) also found that women on average had higher levels of empathy than males, noting that in each field women scored higher than their male peers in the same field. Myyry \& Helkama (2001) found significantly lower level of empathy in men in comparison to women students in technology. 


\subsubsection{Empathy Is Typically Low Among Engineering Population}

While Penprase and colleagues' (2015) study focused on nursing, the authors did find that, engineering and computer science (one combined category) had the lowest levels of empathizing of the nine fields they examined. In the study of college students by Myyry and Helkama (2001), engineering majors scored the lowest on empathy, while social science students had the highest levels of empathy. Altogether, the evidence points to the necessity of consciously incorporating empathy into engineering programs and a professional reformulation of the engineering identity in order to increase enrollment of women.

\subsection{Conceptual Framework}

Empathy as a concept started in ancient Greece and became a topic in psychological research a few decades ago (Rasoal et al., 2012). Some researchers argue that empathy involves both a cognitive and an affective component (Hoffman,1977, 1981; see also Myyry \& Helkama, 2001), nonetheless both emotional and cognitive components of empathy are rooted in one's awareness of others' experiences and the ability to see and experience from others' perspective (Sheldon, 1996; Rasoal et al., 2012). That is, empathic persons are more likely to pay attention to subjective experience, as viewed from the perspective of the experiencer.

Approaching empathy from a more analytical perspective, Baron-Cohen (2002; see also Baron-Cohen et al., 2003) suggests that there are actually two psychological dimensions contributing to sex differences; in addition to empathizing (E), the opposite but complementary dimension is systemizing (S). Empathizing is defined as the drive to "identify another person's thoughts and feelings and to respond to these with an appropriate emotion" (Baron-Cohen, 2002, p. 991). Systemizing is the cognitive style that complements empathizing, and it drives individuals to analyze the variables in a system, to understand the rules that govern the behavior of a system, and to be able to construct systems (Baron-Cohen, 2002). Empathizing and systemizing are fundamental ways in which people interact with the world, and evidence is strong that females "adopt on average a more empathizing style, while males adopt on average a more systemizing style of information processing” (p. 2848, Groen et al., 2015; Rasoal et al., 2012).

STEM disciplines, including engineering, are perceived as focusing on systematic study, based on observation, experimentation, and quantitative manipulation (Manson \& Winterbottom, 2012). To better understand the role of empathy in women's low presence in engineering programs, in this study, the quantification of empathy is based on Baron-Cohen's (2009) empathizing-systemizing theory (E-S theory) of sex differences. The Empathy Quotient (EQ) measure the level of an individual identifying with the thoughts, emotions, and feelings of others. The Systemizing Quotient (SQ) measure a person's tendency for analyzing, exploring, and constructing systems (Baron-Cohen et al., 2003). Individuals with higher standardized scores on the EQ than the SQ are categorized as "type E", whereas individuals with higher scores on the SQ than the EQ are categorized as "type S". Individuals having equal EQ and SQ are categorized as "type B" (Groen et al., 2015).

\subsection{Research Interests}

To date engineering remains one of the most sex-segregated professional occupations (Mann \& DiPrete, 2013). Countless research and intervention projects have been developed to promote women's entry in to engineering, the rather consistent findings are that, first, lack of competence is an invalid argument for the low presence of women in STEM majors because evidence support that female and male students exhibit equal performance in sciences at the undergraduate level (Dickson, 2010; Glynn, Taasoobshirazi, \& Brickman, 2007) and there is no innate gender difference in technical ability between women and men (Faulkner, 2000). Second, engineering is primarily a male dominated profession. Women engineers often have to battle cultural, structural and organizational obstacles in their educational and professional endeavors as a marginalized minority group (Mann \& DiPrete, 2013).

Rather than calling for women to make changes in order to gain better access to and a more equitable share in the engineering labor market, this study focuses on exploring how the lack of empathy and human-centered perspective in engineering education may influence women's decisions about entering engineering programs and professions. We will use empirical data to answer the following research questions:

1) How do male and female students differ in their EQ-SQ traits?

2) How do gender-based EQ-SQ differences, if any, relate to students' perception of and preferences to engineering majors in comparison to other academic majors?

3) What evidence supports that empathy, or the lack of it, is a factor in the underrepresentation of women in engineering majors?

4) How does personally knowing an engineer influence the likelihood of an individual choosing an engineering major? 


\section{Method}

\subsection{Instrument}

An online survey was developed and used to measure empathizing and systemizing quotients in students at all stages of college education. The survey included eight questions about EQ (Cronbach $\alpha=0.88$ ) and four questions about SQ (Cronbach $\alpha=.70$ ) extracted from the EQ-SQ instrument developed by Baron-Cohen and Wheelwright (2004) to measure the level of empathy in individual respondents. A subset of 12 questions were extracted from the original instrument because the total number of questions was too large to accommodate in the current study. The subset of questions was chosen based on factor analysis of the original instrument and content checks to match the goal of the present study (Wakabayashi et al., 2006). And so, consideration was taken to capture the three essential qualities of empathy that appear in the body of literature including the cognitive component (knowing what another person is feeling), the emotional component (feeling what another person is feeling), and the responding component (responding with compassion to another person) (Levenson \& Ruef, 1992).

The online survey additionally included items measuring 1) the level of empathy perceived by the student for a list of twenty-one academic majors and 2) their self-reported likelihood of pursuing one of those majors. There were also a series of statements questioning respondents about the level of empathy they perceived among faculty and other students within their major. Finally, the survey captured basic demographic information such as gender, age, current or planned major, and status (freshman, sophomore, junior, senior) in undergraduate education (see the Appendix for complete survey questions).

\subsection{Sampling and Participants}

Data was collected using stratified sampling at an urban university in the mid-South area in the spring of 2017. In 2017, the university had an enrollment size of over 20,000, of which approximately 1,000 full-time students were in the College of Engineering. In order to have sufficient representation of engineering students, all undergraduate students in the College were contacted by email and encouraged to respond to the online survey. For non-engineering majors, a sample of 3,000 students was randomly selected and contacted. A total of 639 responses were recorded by the end of May 2017. The final sample of respondents, after data cleaning and preparation that removed incomplete and invalid responses, included 517 undergraduate students. The sample was comprised of $54 \%$ male and $46 \%$ female. Respondents were also identified as STEM $(n=257)$ vs. non-STEM $(n=260)$ majors. Of the students who were engineering majors, 160 were males and 69 were females.

\subsection{Analytical Procedures}

The primary measure of interest in this study was empathy as captured by the EQ questions. Since the literature suggests that empathizing (EQ) and systemizing (SQ) are two fundamentally related, but practically opposite ways that individuals interact with their surroundings, we combined the two measures by taking the ratio of EQ/SQ scores. That is, we coded the questions so that $\mathrm{EQ} / \mathrm{SQ}=1$ indicates a balance between the two traits (Type $\mathrm{B}$ ); $\mathrm{EQ} / \mathrm{SQ}>1$ indicates a stronger trait of empathizing (Type $\mathrm{E}$ ); and $\mathrm{EQ} / \mathrm{SQ}<1$ indicates a stronger trait of systemizing (Type $\mathrm{S}$ ). To answer the first research question, descriptive statistics and preliminary comparisons were used to examine gender differences in the $\mathrm{EQ} / \mathrm{SQ}$ ratio and how the differences are shown in various academic majors. For research question two, an Analysis of Covariance (ANCOVA) was used to investigate how the perceived levels of empathy in academic majors varied between genders, controlling for their differences in the EQ/SQ ratio. Finally, for research questions three and four, multiple regression analysis was used to examine whether the likelihood of choosing a particular engineering major is associated with factors including student's gender, beliefs about the level of empathy associated with that discipline, and personally knowing an engineer, while controlling for the EQ/SQ ratio.

\section{Results}

Based on the sample of 229 female students and 266 male students, the analysis indicated that female students had an average of 1.39 on the EQ/SQ ratio, which was significantly higher $(\mathrm{p}<.001)$ than the average of male students $(1.05)$. However, further examination of the data (see Table 1) also revealed that students in non-STEM academic majors had higher EQ/SQ ratios than their counterparts in engineering majors, with female students in non-STEM majors having the highest $\mathrm{EQ} / \mathrm{SQ}$ ratio (1.49). It is also clear that the EQ/SQ ratio (1.16) of female students in engineering majors suggested a relative balance between empathizing and systemizing, whereas females in non-STEM majors had a much greater tendency for empathizing over systemizing (1.49). In engineering majors that had sufficient sample sizes $(n>5)$, the general pattern was that female students had higher EQ/SQ ratios than male students. However, for the three engineering majors with very small sample size (civil engineering, computer/electrical engineering, and engineering technology), the few female students reported lower EQ/SQ ratios than their male peers (see Table 1; certain data patterns should be interpreted with caution due to extremely small sample sizes). 
Since female students are found to have stronger empathizing traits than male students, do they perceive engineering professions differently than their male counterparts? To answer this question, the perceived empathy levels reported by students for twenty-one academic majors were compared. In order to identify the general patterns, the twenty-one professions were separated into three groups: engineering, other STEM, and non-STEM. Student evaluations of the level of empathy associated with these professions were totaled within each of the three categories. Descriptive examination of the data suggested that students' EQ/SQ ratio was positively related to the empathy evaluations of non-STEM majors $(r=.113)$ but negatively related to that of the engineering majors $(r=-.145)$ and other STEM majors $(r=-.119)$, thus the EQ/SQ ratio was included as a covariate in ANCOVA models after the assumptions of homogeneity of regression and homogeneity of variance were verified. The dependent variable was the perceived level of empathy of the grouped professions, the independent variables were gender and whether students was an engineering major (yes vs. non-STEM, other STEM majors were excluded).

Table 1. Comparison of the EQ/SQ ratio between genders

\begin{tabular}{|c|c|c|c|c|c|}
\hline \multirow[t]{2}{*}{ Major } & \multicolumn{2}{|c|}{$\begin{array}{c}\text { EQ/SQ ratio } \\
(n)\end{array}$} & \multirow[t]{2}{*}{ Test of significance } & \multirow[t]{2}{*}{$F$} & \multirow[t]{2}{*}{$p$} \\
\hline & Female & Male & & & \\
\hline Total & $\begin{array}{l}1.39 \\
(229)\end{array}$ & $\begin{array}{l}1.05 \\
(266)\end{array}$ & Female vs. Male & & $<0.001$ \\
\hline Engineering & $\begin{array}{l}1.16 \\
(68)\end{array}$ & $\begin{array}{l}1.02 \\
(161)\end{array}$ & Female vs. Male & 41.576 & $<0.001$ \\
\hline $\begin{array}{l}\text { Mechanical } \\
\text { engineering }\end{array}$ & $\begin{array}{l}1.11 \\
(17)\end{array}$ & $\begin{array}{l}1.00 \\
(74)\end{array}$ & & 2.085 & 0.152 \\
\hline $\begin{array}{l}\text { Biomedical } \\
\text { engineering }\end{array}$ & $\begin{array}{l}1.28 \\
(35)\end{array}$ & $\begin{array}{l}1.10 \\
(22)\end{array}$ & & 5.350 & 0.025 \\
\hline $\begin{array}{l}\text { Electric } \\
\text { engineering }\end{array}$ & $\begin{array}{l}1.12 \\
(6)\end{array}$ & $\begin{array}{l}0.97 \\
(21)\end{array}$ & & 2.357 & 0.137 \\
\hline $\begin{array}{l}\text { Civil } \\
\text { engineering }\end{array}$ & $\begin{array}{l}0.83 \\
(1)\end{array}$ & $\begin{array}{l}1.09 \\
(14)\end{array}$ & & & \\
\hline Computer \& EE & $\begin{array}{l}0.69 \\
(3)\end{array}$ & $\begin{array}{l}1.07 \\
(12)\end{array}$ & $\begin{array}{l}\text { Unavailable due to small } \\
\text { students in }\end{array}$ & $\begin{array}{l}n<5) \text { of } \\
\text { le }\end{array}$ & female \\
\hline $\begin{array}{l}\text { Engineering } \\
\text { technology }\end{array}$ & $\begin{array}{l}0.76 \\
(2)\end{array}$ & $\begin{array}{l}0.96 \\
(8)\end{array}$ & & & \\
\hline $\begin{array}{l}\text { Other } \\
\text { engineering }\end{array}$ & $\begin{array}{l}1.02 \\
(5)\end{array}$ & $\begin{array}{l}0.97 \\
(11)\end{array}$ & & & \\
\hline Non-STEM & $\begin{array}{l}1.49 \\
(144)\end{array}$ & $\begin{array}{l}1.12 \\
(94)\end{array}$ & STEM vs. non-STEM & 30.779 & $<0.001$ \\
\hline
\end{tabular}

The results (shown in Table 2) indicated that although female students perceived the levels of empathy associated with the professions in engineering and other STEM fields relatively lower than their male counterparts, the gender-related differences in perceived empathy levels of the majors were statistically nonsignificant and practically minor. Rather, engineering students reported empathy levels of engineering and STEM professions in general significantly higher $(p$ $<.001)$ than their counterparts in non-STEM major, indicating that engineering and STEM students perceived their own fields as empathetic while non-STEM students viewed those fields as less empathetic.

With regard to non-STEM majors, different patterns were found. Students in both engineering and non-STEM majors offered very similar ratings of the empathy level of non-STEM professions, but female students perceived the non-STEM profession as having higher empathy level than male students $(p=.001)$. Further analyses by individual engineering majors did reveal that female students perceived higher empathy levels in biomedical engineering than male students, but gender-related differences did not exist for other engineering majors. In all, the EQ/SQ ratio of students as the covariate did not contribute significantly to the level of perceived empathy in different professions. 
Nonetheless, on average students perceived the empathy level of non-STEM professions (3.48) to be significantly higher $(\mathrm{p}<.001)$ than that of the engineering professions (3.19).

Table 2. Perceived level of empathy associated with professions in Engineering, other STEM, and non-STEM. Comparison by gender and engineering vs. non-STEM majors

\begin{tabular}{|c|c|c|c|c|c|c|c|c|}
\hline \multicolumn{3}{|c|}{$\begin{array}{c}\text { Perceived level of } \\
\text { empathy }\end{array}$} & \multicolumn{2}{|c|}{$\begin{array}{l}\text { Engineering } \\
\text { professions }\end{array}$} & \multicolumn{2}{|c|}{$\begin{array}{c}\text { Other STEM } \\
\text { professions }\end{array}$} & \multicolumn{2}{|c|}{$\begin{array}{l}\text { Non-STEM } \\
\text { professions }\end{array}$} \\
\hline Gender & Academic major & $n$ & Mean & Std. & Mean & Std & Mean & Std. \\
\hline \multirow{3}{*}{ Male } & Non-STEM students & 88 & 3.03 & 0.89 & 2.59 & 0.87 & 3.29 & 0.64 \\
\hline & Engineering students & 157 & 3.44 & 0.87 & 3.00 & 0.78 & 3.35 & 0.72 \\
\hline & All male students & 245 & 3.29 & 0.90 & 2.94 & 0.80 & 3.33 & 0.62 \\
\hline \multirow{3}{*}{ Female } & Non-STEM students & 140 & 2.94 & 0.85 & 2.66 & 0.74 & 3.59 & 0.62 \\
\hline & Engineering students & 67 & 3.44 & 0.70 & 3.02 & 0.65 & 3.55 & 0.69 \\
\hline & All female students & 207 & 3.10 & 0.84 & 2.80 & 0.73 & 3.58 & 0.64 \\
\hline \multirow{3}{*}{ All } & Non-STEM students & 228 & 2.97 & 0.86 & 2.65 & 0.77 & 3.47 & 0.64 \\
\hline & Engineering students & 224 & 3.44 & 0.83 & 3.01 & 0.74 & 3.41 & 0.71 \\
\hline & All students & 452 & 3.21 & 0.88 & 2.87 & 0.77 & 3.44 & 0.68 \\
\hline
\end{tabular}

Knowing that male and female students did not differ in their perception of engineering professions with regards to empathy level, we sought to find out whether there were any EQ-SQ related factors contributed to gender imbalance in engineering majors. Using the reported likelihood of choosing an engineering majors (i.e., biomedical engineering, civil engineering, mechanical engineering, electrical engineering, and computer engineering) as the dependent variables, student EQ/SQ ratio was included as a covariate, gender and perceived level of empathy of the major were the independent variables, five ANCOVA models of identical structure were constructed. In all of them, another variable included in the model was whether a student personally knew an engineer.

Table 3. Relative likelihood of choosing an Engineering major as a function gender, controlling for EQ/SQ ratio and STEM/non-STEM major. ( $\alpha=.01$ to lower the chance for Type I error)

\begin{tabular}{|c|c|c|c|c|}
\hline \multirow[b]{2}{*}{ Academic Major } & \multicolumn{4}{|c|}{ TYPE III SS } \\
\hline & EQ/SQ Ratio & $\begin{array}{l}\text { X1: Gender } \\
\text { (means of Female } \\
\text { vs. Male) }\end{array}$ & $\begin{array}{l}\text { X2: Perceived Level of } \\
\text { Empathy }\end{array}$ & $\begin{array}{l}\text { X3: Personally Know } \\
\text { an Engineer }\end{array}$ \\
\hline Civil Engineering (4) & $10.77^{* *}$ & $\begin{array}{l}55.39 * * * \\
(1.93 \text { vs. } 2.74)\end{array}$ & $65.79 * * *$ & 5.19 \\
\hline $\begin{array}{l}\text { Mechanical } \\
\text { Engineering (7) }\end{array}$ & $55.94 * * *$ & $\begin{array}{l}87.52 * * * \\
(2.24 \text { vs. } 3.26)\end{array}$ & $99.57 * * *$ & $27.98 * * *$ \\
\hline $\begin{array}{l}\text { Electrical } \\
\text { Engineering (9) }\end{array}$ & $29.84 * * *$ & $\begin{array}{l}82.35^{* * * *} \\
(2.03 \text { vs. } 3.02)\end{array}$ & $75.17 * * *$ & $13.29^{*}$ \\
\hline $\begin{array}{l}\text { Biomedical } \\
\text { Engineering (13) }\end{array}$ & $19.09 * * *$ & $\begin{array}{l}2.23 \\
(2.83 \text { vs. } 2.99)\end{array}$ & $73.412 * * *$ & 0.18 \\
\hline $\begin{array}{l}\text { Computer } \\
\text { Engineering (17) }\end{array}$ & $53.78 * * *$ & $\begin{array}{l}44.69 * * * \\
(2.28 \text { vs. } 3.01)\end{array}$ & $72.12 * * *$ & 1.00 \\
\hline
\end{tabular}

The results are presented in Table 3. Student EQ/SQ ratio was significantly related to the likelihood of choosing an engineering major in a negative manner; further analysis by gender groups indicated that this pattern was true for both male and female students. The second consistent pattern was between the perceived level of empathy and the likelihood of choosing an engineering major. For all five engineering majors, the higher a student perceived the level of empathy of a given major, the higher the reported likelihood of choosing that major $(\mathrm{p}<.001)$. With the effect of $E Q / S Q$ ratio and perceived empathy level removed, female students still had significantly lower likelihood of choosing an engineering major with the only exception of biomedical engineering. Interestingly, personally knowing an engineer 
significantly increased students' likelihood of majoring in mechanical engineering and electronical engineering, but did not make a difference for choosing civil engineering, computer engineering, or biomedical engineering.

\section{Discussion}

The study provided clear answers to all four research questions. For research question one, the primary analysis of data confirmed that there was a substantial gender difference in the empathizing/systematizing traits, with women having much higher tendency than men on empathizing and concerning with the wellbeing of others (Andrew et al., 2008; Baron-Cohen et al., 2003; Rasoal et al., 2012; Willer et al., 2015). Also, students in engineering scored significantly lower than their counterparts in non-STEM majors on the EQ/SQ ratio, indicating their relative emphasis on systematizing over empathizing (Myyry \& Helkama, 2001; Penprase et al., 2015). Both findings confirmed the general patterns reported in the literature.

Additionally, the study has new revelations. The collected evidence for answering the second research question suggests that students perceived engineering majors as having lower empathy levels than non-STEM majors. Note that their ratings of empathy levels of the academic disciplines were not related to their personal EQ-SQ trait. Neither male nor female students showed significant differences in their perceptions. Interestingly though, students in engineering majors and in non-STEM majors reported comparable ratings of perceived empathy about non-STEM professions, but engineering students rated the empathy level of engineering professions significantly higher than the ratings by the non-STEM majors. A possible interpretation of this difference is that the curricula in engineering programs enabled students to learn about and make connections with the welfare of stakeholders, such as understanding problems from the users' perspective and developing user-appropriate design solution. Nonetheless, there is a lack of effective communication about utilizing empathy in engineering design, and outsiders are mostly unaware of the efforts and skills of engineer professions in developing and translating social concerns and responsibilities into innovative and meaningful engineering action.

An unemphatic image of engineer professions also helps explain the low presence of women in engineering. In the process of seeking an answer for research question three, the study found that higher scores in empathy (i.e., higher EQ/SQ ratio) negatively predicted students' likelihood of choosing an engineering major. Given that female students not only scored much higher on the empathy scale, but also rated the empathy level of engineering professions very unfavorably, their decreased likelihood of choosing engineering as academic major became understandable. The finding can be interpreted from the perspective of professional identity. Evidence from the literature is convincing that empathy contributes to women's construction of professional identity (Jacobs et al., 2016; Myyry \& Helkama, 2001; Öhlén \& Segesten, 2002); the perceived lack of empathy in the engineer professions mismatches with women's professional values and thus became detrimental to their likelihood of choosing an engineering major. The proposition that the lower likelihood of female students choosing engineering was related to their perception of engineering as having lower empathy levels can be further collaborated by the observation that the likelihood of choosing biomedical engineering as a major was similar between male and female students when comparable levels of perceived empathy were reported by the two gender groups. In short, this study provides evidence concerning the (lack of) congruency between women's personal and professional identity traits and the values espoused by different fields in engineering.

Furthermore, the negative relationship between students' likelihood of choosing an engineering major and the perceived level of empathy associated with practitioners in the related professions was not limited to women only; the same was found for men as well, a finding suggesting the important role of empathy in major selection regardless of gender (Manson \& Winterbottom, 2012). The perceived lack of empathy in engineering professions is troublesome due to the fact that service to society is an important characteristic expected in engineering students as they will apply their knowledge and skill sets for the benefit and advancement of human welfare (NSPE, 2018).

In order to attract more women students and students with high empathic thinking to the engineering field, changes are necessary in two areas. The first is to structure teaching practices that systemize the approaches of developing and practicing empathy in engineering courses; the other is to update the common perception of engineering professionals through educating general public about the depth and breadth of services and contributions that engineer professions provide to society (Penzenstadler, Haller, Schlosser, \& Frenzel, 2009). In other words, it is important to take greater efforts to connect the stated values and missions of engineering and the broader welfare of society and human kind both internally and externally to engineering education. Changes in this area will not only enable women to find greater affinity for disciplines such as electrical, computer, and mechanical engineering, but also bring a potentially significant impact on the culture of engineering programs and students as a whole. All students could benefit from an increased emphasis on, exposure to, and experience with empathetic endeavors.

For research question four, the study also found that personally knowing an engineering increased students' reported likelihood of choosing certain engineering majors, including in mechanical engineering and electronical engineering, 
but did not make a difference for choosing civil engineering, computer engineering, or biomedical engineering. It is possible that communication with engineers in certain areas would help students learn more about the empathic components that were not well known outside the professions; whereas in other engineer professions (e.g., civil engineering, computer engineering, or biomedical engineering), the human-centered components (or the lack of) are better understood, and communications at a personal level barely have new revelations that may change the perception of outsiders.

As a final note, it is worth mentioning that the likelihood of women choosing engineering majors, even after controlling for EQ/SQ ratio and perceived empathy level of a given profession, was still significantly lower than men. Apparently, individuals' empathy trait and professional values are important, but they are only two of many factors that are associated with the low presence of women students in engineering. Future research is called to identify more missing pieces in the decades-old puzzle of gender imbalance in engineer majors and professions.

The two major limitations are both related to the sample used in this study. First, the sample consisted of undergraduate students from one mid-South university. Generalizability of the findings is restricted to only institutions and students of comparable characteristics. Second, some of findings were based on very small samples. Specifically, findings related to gender differences in civil engineering, computer/electrical engineering, and engineering technology need to be received with caution due to the the small number of respondents who were women.

\section{Conclusion}

This study examined the role of empathy in the low enrollment of women in engineering majors. The two factors that significantly relate empathy to choosing engineer majors are 1) students' EQ/SQ ratio, in which students with a stronger empathizing trait reported lower likelihood of majoring in engineering, and 2) the perceived empathy level of the professions associated with a given academic discipline, in which lower likelihood of majoring in engineering was associated with the low empathy level perceived of the engineer professions.

Engineering is primarily a male dominated profession, and the engineering professions are perceived to have little concerns about the benefit to mankind (Jacobs et al., 2016). This study explained the identified patterns from the perspective of professional identity. In contrast, women have a stronger tendency to empathizing; empathy is an important element of women's professional identity. This mismatch between women's core values and those of the field apparently contributes to the low likelihood of women pursuing engineering majors. Even though the significantly lower likelihood of women choosing engineering majors still existed after controlling for empathy-related factors, the significant findings of the study call for reformulation of the engineering education field, so that human-centered values can be added as critical components to the existing curricula. It is also worth the effort to better communicate with the general public about how empathy and services to society are fundamentally incorporated in the practice of engineer professions.

\section{Acknowledgement}

This project is funded by the National Science Foundation under Grant No. 1640440 awarded to Drs. Eddie Jacobs (PI), Amy Curry, Yonghong Xu, Carmen Astorne-Figari, and Russell Deaton. Any opinions, findings, and conclusions or recommendations expressed herein are those of the authors and do not necessarily reflect the views of the National Science Foundation.

\section{References}

ABET Engineering Accreditation Commission. (2018). Criteria for accrediting engineering programs. Baltimore, MD: ABET. Retrieved October 15, 2018, from http://www.abet.org/eac-criteria-2014-2015/ on

Adams, K., Hean, S., Sturgis, P., \& Clark, J. M. (2006). Investigating the factors influencing professional identity of first-year health and social care students. Learning in Health and Social Care, 5(2), 55-68.

Andrew, J., Cooke, M., \& Muncer, S. J. (2008). The relationship between empathy and Machiavellianism: An alternative to empathizing-systemizing theory. Personality and Individual Differences, 44, 1203-1211. https://doi.org/10.1016/j.paid.2007.11.014

ASCE, American Society of Civil Engineers. (2017). Code of ethics. Reston, VA: ASCE. Retrieved October 15, 2018, from http://www.asce.org/code_of_ethics/

ASEE, American Society for Engineering Education. (2012). American society for engineering education code of ethics. Retrieved from http://www.asee.org/member-resources/resources/Code_of_Ethics.pdf on December 12, 2019.

Baron-Cohen, S. (2002). The extreme male brain theory of autism. Trends in Cognitive Sciences, 6(6), 248-254.

Baron-Cohen, S. (2009). Autism: The Empathizing-Systemizing (E-S) theory. In M. B. Miller \& A. Kingstone (Eds.), 
Year in Cognitive Neuroscience, 1156, 68-80, NJ: Wiley-Blackwell.

Baron-Cohen, S., \& Wheelwright, S. (2004). The empathy quotient: An investigation of adults with Asperger syndrome or high functioning autism, and normal sex differences. Journal of Autism and Developmental Disorders, 34(2), 163-175. https://doi.org/10.1023/B:JADD.0000022607.19833.00

Baron-Cohen, S., Richler, J., Bisarya, D., Gurunathan, N., \& Wheelwright, S. (2003). The systemizing quotient: An investigation of adults with Asperger syndrome or high-functioning autism, and normal sex differences. Philosophical Transactions of the Royal Society of London Series B-Biological Sciences, 358(1430), 361-374. https://doi.org/10.1098/rstb.2002.1206

Carlsen, L. B., Hermansen M. V., \& VraÊle, G. B. (1984). Sykepleiefaglig Veiledning (Professional Nursing Supervision). Gyldendal, Oslo.

Cech, E. (2014). Culture of disengagement in engineering education? Science, Technology, \& Human Values, 39(1), 42-72. http://dx.doi.org/10.1177/0162243913504305

Dickson, L. (2010). Race and gender differences in college major choice. ANNALS of the American Academy of Political and Social Science, 627, 108-124.

Dizikes, P. (2016). Why do women leave engineering? Study: Group dynamics of teamwork and internships deter many women in the profession. MIT New Office. Retrieved on May 2, 2018 from http://news.mit.edu/2016/why-do-women-leave-engineering-0615

Faulkner, W. (2000). The Power and the pleasure? A research agenda for "making gender stick" to engineers. Science, Technology, \& Human Values, 25(1), 87-119.

Fox, M. F., Sonnert, G., \& Nikiforova, I. (2011). Programs for undergraduate women in

Glynn, S. M., Taasoobshirazi, G., \& Brickman, P. (2007). Nonscience majors learning science: A theoretical model of motivation. Journal of Research in Science Teaching, 44, 1088-1107. doi:10.1002/tea.20181

Griffith, A. L. (2010). Persistent of women and minorities in the STEM field majors: Is it the school that matters. Economics of Education Review, 29, 911-922.

Groen, Y., Fuermaier, A. B. M., Den Heijer, A. E., Tucha, O., \& Althaus, M. (2015). The empathy and systemizing quotient: The psychometric properties of the Dutch version and a review of the cross-cultural stability. Journal of Autism Development Disorder, 45, 2848-2864. https://doi.org/10.1007/s10803-015-2448-z

Heyman, G. D., Martyna, B., \& Bhatia, S. (2002). Gender and achievement-related beliefs among engineering students. Journal of Women and Minorities in Science and Engineering, 8, 41-52. https://doi.org/10.1615/JWomenMinorScienEng.v8.i1.30

Hoffman, M. L. (1977). Empathy, its development and prosocial implications. In C. B. Keasy (Ed.), Nebraska Symposium on Motivation, vol. 25 (pp. 169-217). Lincoln, NE: Nebraska University Press.

Hoffman, M. L. (1981). The development of empathy. In J. P. Rushton \& R. M. Sorrentino (Eds.), Altruism and helping behavior, (pp. 41- 63). Hillsdale, MI: Lawrence Erlbaum Associates.

IEEE. (2018). Mission statement. Retrieved May 2, 2018, from http://www.ieee.org/about/vision_mission.html?WT.mc_id=lp_ab_mav

Jacobs, E., de Jongh Curry, A., Deaton, R. J., Astorne-Figari, C., Strohmer, D. (June 2016). Empathy and gender inequity in engineering disciplines. Paper presented at the annual conference of American Society for Engineering Education: New Orleans, LA.

Kirkpatrick, A. T., Danielson, S., Warrington, R. O., Smith, R. N., Thole, K. A., Kulacki, A., Wepfer, W. J., \& P.E., T. P. (2011, June). Vision 2030: Creating the Future of Mechanical Engineering Education. Paper presented at 2011 ASEE Annual Conference \& Exposition, Vancouver, BC. Retrieved from https://peer.asee.org/18870, on December 12, 2019.

Levenson, R. W., \& Ruef, A. M. (1992). Empathy: A physiological substrate. Journal of Personality and Social Psychology, 63(2), 234-246.

Mann, A., \& DiPrete, T. A. (2013). Trends in gender segregation in the choice of science and engineering majors. Social Science Research, 42(6), 1519-1541.

Manson, C., \& Winterbottom, M. (2012). Examining the association between empathising, systemising, degree subject and gender. Educational Studies, 38(1), 73-88. 
Matusovich, H. M., Streveler, R. \& Miller, R. L. (2010). Why do students choose engineering? A qualitative, longitudinal investigation of students' motivational values. Journal of Engineering Education, 99(4), 289-303. https://doi.org/10.1002/j.2168-9830.2010.tb01064.x

McGowen, K. R., \& Hart, L. E. (1990) Still different after all these years: Gender differences in professional identity formation. Professional Psychology: Research and Practice, 21, 118-123.

Myyry, L., \& Helkama, K. (2001). University students' value priorities and emotional empathy. Educational Psychology, 21(1), 25-40. https://doi.org/10.1080/01443410020019812

National Science Foundation (NSF). Science and engineering indicators 2014. Retrieved December 12, 2018, from https://www.nsf.gov/statistics/seind14/index.cfm/chapter-3/c3s5.htm

National Society of Professional Engineers (NSPE). Engineers creed. Retrieved May 2, 2018, from

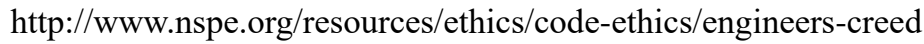

Öhlén, J., \& Segesten, K. (2002). The professional identity of the nurse: Concept analysis and development. Journal of Advanced Nursing, 28, 720-727.

Penprase, B., Oakley, B., Ternes, R., \& Driscoll, D. (2015). Do higher dispositions for empathy predispose males toward careers in nursing? A descriptive correlational design. Nursing Forum 50(1), 1-8, https://doi.org/10.1111/nuf.12058

Penzenstadler, B., Haller, G., Schlosser, T., \& Frenzel, G. (2009). Soft Skills REquired: A practical approach for empowering soft skills in the engineering world. Proceedings of the 2009 Collaboration and Intercultural Issues on Requirements: Communication, Understanding and Soft skills, 31-36.

Rasoal, C., Danielsson, H., \& Jungert, T. (2012). Empathy among students in engineering programmes. European Journal of Engineering Education 37(5), 427-435. https://doi.org/10.1080/03043797.2012.708720

science and engineering: Issues, problems, and solutions. Gender \& Society, 25, 589-615. https://doi.org/10.1177/0891243211416809

Sheldon, K. M. (1996). The social awareness inventory: Development and applications. Personality and Social Psychological Bulletin, 6, 620-634. https://doi.org/10.1177/0146167296226007

Strobel, J., Hess, J., Pan, R., Wachter, C., \& Morris, A. (2013). Empathy and care within engineering: Qualitative perspectives from engineering faculty and practicing engineers. Engineering Studies, 5(2), 137-159. https://doi.org/10.1080/19378629.2013.814136

Wakabayashi, A., Baron-Cohen, S., Wheelwright, S., Goldenfeld, N., Delaney, J., Fine, D., Smith, R., \& Weil, L. (2006). Development of short forms of the Empathy Quotient (EQ-Short) and the Systemizing Quotient (SQ-Short). Personality and Individual Differences, 41, 929-940. https://doi.org/10.1016/j.paid.2006.03.017

Willer, R., Wimer, C., \& Owens, L. A. (2015). What drives the gender gap in charitable giving? Lower empathy leads men to give less to poverty relief. Social Science Research, 52, 83-98. https://doi.org/10.1016/j.ssresearch.2014.12.014

$\mathrm{Xu}$, Y. J. (2015). Gender-based earning gap of college graduates: Modeling ten-year progress for STEM and Non-STEM comparisons. The Journal of Higher Education, 86, 489-523.

$\mathrm{Xu}$, Y. J. (2016). Aspiration and application for graduate education: Gender differences in Low-Participation STEM disciplines. Research in Higher Education, 57(8), 913-942.

Zhang, L. (2008). Gender and racial gaps in earnings among recent college graduates. The Review of Higher Education, 32, 51-72. https://doi.org/10.1353/rhe.0.0035 


\section{Appendix A}

Q1: Empathy is defined as an ability to identify on an emotional level with another person, group, or society as a whole, coupled with a desire to help them. What are your beliefs regarding the level of empathy associated with practitioners of each of the following professions?

$\begin{array}{lllll}\text { Strongly } & \text { Unconcerned } & \text { Neutral } & \text { Concerned } & \text { Strongly } \\ \text { Unconcerned (1) } & (2) & (3) & (4) & \text { Concerned (5) }\end{array}$

Biology (1)

Statistics (2)

Psychology (3)

Civil Engineering (4)

Mathematics (5)

Accounting (6)

Mechanical Engineering (7)

Chemistry (8)

Electrical Engineering (9)

Nursing (10)

Economics (11)

Elementary Education (12)

Biomedical Engineering (13)

Computer Science (14)

Art (15)

Music (16)

Computer Engineering (17)

Business Administration (18)

History (19)

English (20)

Physics (21)

Q2 How likely would you be to choose to major or minor in each of the following subjects if you were free to make the choice?

[Same table structure as in Q1, with the five choices as:

Highly Unlikely (1) Unlikely (2) Don't Know (3)Likely (4) Highly Likely (5)]

Q3 If you are having trouble with a subject, what would be your strategy to overcome it? Rank the following options by 
dragging an item to its desired position. Put the most likely choice at the top.

Ask a friend studying the same subject. (1)

Ask a student who you know is doing well in the subject. (2)

Ask a tutor. (3)

Ask a teaching assistant for the class. (4)

Ask the person who teaches the class. (5)

Work it out on my own. (6)

Q4 Please indicate your agreement with the following statements.

[Each statement is followed by five choices: Strongly disagree (1) Somewhat disagree (2) Neither agree nor disagree (3) Somewhat agree (4) Strongly agree (5)]

I feel supported by other students in my department.

The faculty do not care about my success in this program.

I do not find many students in my department who have the same challenges I do.

Most faculty seem to identify with students.

I can tell when other students are struggling in a class.

The faculty are not sensitive to the challenges students face.

My fellow students often offer help without me asking.

Faculty are seldom helpful when I have a problem.

I volunteer to organize study groups for my classes.

The Faculty in this department value me as a student.

Q5 Please indicate your level of agreement with the following statements.

[Each statement is followed by five choices: Strongly disagree (1) Somewhat disagree (2) Neither agree nor disagree (3) Somewhat agree (4) Strongly agree (5)]

I find it easy to put myself in somebody else's shoes.

I am good at predicting how someone will feel.

I am quick to spot when someone in a group is feeling awkward or uncomfortable.

Other people tell me I am good at understanding how they are feeling or what they are thinking.

Friends usually talk to me about their problems as they say that I am very understanding.

I can tune into how someone else feels rapidly and intuitively.

I can easily work out what another person might want to talk about.

I can tell if someone is masking their true emotion.

If I were buying a car, I would want to obtain specific information about its engine characteristics.

I am fascinated by how machines work.

I find it difficult to understand instruction manuals for putting appliances together.

If I were buying a smart phone, I would want to know about its precise technical features.

Q6 How old are you?

\begin{tabular}{lll} 
o & \multicolumn{2}{c}{ Under 13} \\
o & $13-17$ & $(2)$ \\
o & $18-25$ & $(3)$ \\
o & $26-34$ & $(4)$
\end{tabular}



o $\quad 35-54 \quad(5)$
o 55 or over (6)

Q7 What is your gender?

o Male (1)

o Female (2)

Q8 What is your race?

o White/Caucasian (1)

o African American (2)

o Hispanic (3)

o Asian (4)

o Native American (5)

o Pacific Islander (6)

o Other (7)

Q9 What is the highest level of education you have completed?
o Less than High School (1)
o High School / GED
o Some College (3)
o 2-year College Degree
o 4-year College Degree
o Masters Degree (6)
o Doctoral Degree (7)
o Professional Degree (JD, MD)

Q10 What is your intended or current major?

Q11 Do you personally know an engineer?
o Yes (1)
o Maybe (2)
o No (3)

Q12 Did the engineer you know change your perception/likelihood of entering an engineering major?
o Yes (1)
o Maybe (2)
o No (3)

\section{Copyrights}

Copyright for this article is retained by the author(s), with first publication rights granted to the journal.

This is an open-access article distributed under the terms and conditions of the Creative Commons Attribution license which permits unrestricted use, distribution, and reproduction in any medium, provided the original work is properly cited. 